\title{
KANDUNGAN PIPERIN DALAM EKSTRAK BUAH LADA HITAM DAN BUAH LADA PUTIH (Piper nigrum L.) YANG DIEKSTRAKSI DENGAN VARIASI KONSENTRASI ETANOL MENGGUNAKAN METODE KLT-DENSITOMETRI
}

\author{
THE CONTENT OF PIPERINE IN BLACK AND WHITE \\ PEPPER FRUITS (Piper nigrum L.) EXTRACTED \\ WITH VARIATION OF ETHANOL CONCENTRATIONS \\ USING TLC-DENSITOMETRY METHOD
}

\author{
Ni Putu Ermi Hikmawanti, Hariyanti, Cahya Aulia, Vesya Putri Viransa \\ Jurusan Farmasi, Fakultas Farmasi dan Sains, \\ Universitas Muhammadiyah Prof. Dr. Hamka, Jakarta \\ Email: ermy0907@gmail.com
}

\begin{abstract}
ABSTRAK
Kualitas ekstrak buah lada (Piper nigrum L.) dipengaruhi oleh komponen dan kadar senyawa didalamnya. Piperin merupakan senyawa alkaloid utama dalam buah lada. Banyaknya piperin yang larut selama proses ekstraksi dipengaruhi oleh jenis pelarut yang digunakan. Penelitian ini didesain untuk mengetahui kadar piperin dalam ekstrak buah lada hitam dan lada putih yang diekstraksi dengan variasi konsentrasi etanol. Ekstraksi buah lada dilakukan dengan metode ekstraksi sokhlet menggunakan variasi konsentrasi etanol $(60 \%, 70 \%$ dan $96 \%$ ) dan kemudian dilanjutkan dengan teknik ekstraksi asam-basa untuk mendapatkan ekstrak alkaloidnya. Ekstrak alkaloid masing-masing dianalisis pada plat KLT silika gel $60 \mathrm{~F}_{254}$ sebagai fase diam dan campuran $n$-heksana:etil asetat $(1: 1)$ sebagai fase gerak. Kadar piperin ditetapkan menggunakan metode KLTdensitometri pada panjang gelombang $254 \mathrm{~nm}$. Hasil menunjukkan bahwa kadar piperin tertinggi diperoleh dari ekstrak buah lada hitam menggunakan pelarut

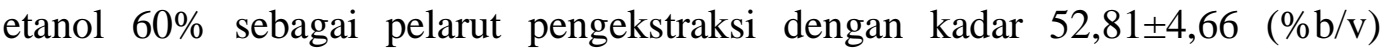
terhadap ekstrak alkaloidnya. Kadar piperin tertinggi diperoleh dari ekstrak buah lada putih menggunakan pelarut etanol dengan konsentrasi $96 \%$ sebagai pelarut pengekstraksi dengan kadar 38,72 $\pm 8,28$ (\%b/v) terhadap ekstrak alkaloidnya.
\end{abstract}

Kata Kunci: etanol, piperin, lada, Piper nigrum L., KLT-densitometri

\begin{abstract}
Quality of pepper fruit extracts (Piper nigrum L.) is influenced by its components and concentration of compounds. Piperine is a major alkaloid compound in pepper fruits.The level of piperine that dissolved during extraction process was influenced by the type of solvent used.This research was designed to know the
\end{abstract}


level of piperine in black and white pepper fruits extracted with variation of ethanol concentrations. Extraction of pepper fruits was performed with soxhlet apparatus using variation of ethanol concentration $(60 \%, 70 \%$, and $96 \%)$ and then continued withacid-base extraction technique to get its alkaloids fraction. Each of alkaloids fractions was analyzed on silica gel $60 F_{254}$ TLC plate as stationary phase and mixture of n-hexane:etyl acetate (1:1) as mobile phase. The level of piperine was determined using TLC-densitometry at wavelength $254 \mathrm{~nm}$. The results showed that highest level of piperine obtained from black pepper fruit extract using ethanol $60 \%$ as extraction solvent with rate of $52.81 \pm 4.66(\% \mathrm{w} / \mathrm{v})$ toward its alkaloids fraction. While highest level of piperine obtained from white pepper fruit extract using ethanol $96 \%$ as extraction solvent with rate of $38.72 \pm 8.28(\% \mathrm{w} / \mathrm{v})$ toward its alkaloids fraction.

Keywords: ethanol, piperine, pepper, Piper nigrum L., TLC-densitometry

\section{PENDAHULUAN}

Lada atau yang disebut juga merica (Piper nigrum L.) berasal dari famili Piperaceae (Vasavirama dan Upender, 2014). Pada umumnya lada hitam (black pepper) dimanfaatkan sebagai bumbu dapur, sama halnya dengan lada putih (white pepper). Lada putih diperoleh dari buah lada hitam yang buah-buahnya dipetik selagi masih hijau atau hampir masak, direndam untuk memudahkan pengupasan lapisan luar perikarp, lalu dijemur sampai kering (Kartasapoetra, 2004).

Buah lada hitam mengandung alkaloid dan minyak atsiri dengan komponen felandren, dipenten, kariopilen, entoksilen, dan limonen (Depkes RI, 1980). Lada hitam juga mengandung antara lain alkaloid piperin (5,3-9,2\%), kavisin (sampai $1 \%$ ) dan metil-pirolin; minyak atsiri (1,2-3,5\%); lemak (6,5-7,5\%); pati (36-37\%) dan serat kasar $( \pm 14 \%)$ (Loo, 1987). Buah lada putih mengandung alkaloid seperti piperin, kavisin, dan metilpirolin, serta minyak atsiri, lemak dan pati. Kandungan utama dalam lada adalah alkaloid piperin. Piperin memiliki rumus molekul C17H19NO3 atau (E,E)-1-[5-(1,3-benzodioksol-5-il)-1-okso-2,4-pentadienil] piperidin, diperoleh dalam bentuk prisma monosiklik dari alkohol dengan titik lebur $130^{\circ} \mathrm{C}, 1 \mathrm{~g}$ piperin larut dalam $15 \mathrm{~mL}$ etanol, $36 \mathrm{~mL}$ eter dan hampir tidak larut dalam air (Kar, 2014). Piperin berbentuk kristal berwarna putih kekuningan dan merupakan alkaloid dari golongan piperidin yang memiliki sifat hampir tidak 
larut dalam air $\left(40 \mathrm{mg} / \mathrm{L}\right.$ pada suhu $\left.18^{\circ} \mathrm{C}\right)$, namun mudah larut dalam alkohol (1 $\mathrm{g} / 15 \mathrm{~mL}$ ) dan eter (1 g/1,7 mL) (Vasavirama dan Upender, 2014).

Piperin memiliki khasiat sebagai antiinflamasi, antimalaria, menurunkan berat badan, menurunkan demam, menetralkan racun bisa ular, antiepilepsi, membantu meningkatkan penyerapan vitamin tertentu (Kolhe et al., 2009). Piperin memiliki aktivitas sebagai analgesik dan antipiretik pada tikus, dan menunjukkan hasil yang sebanding dengan indometasin sebagai obat standar (Sabina et al., 2013). Kualitas ekstrak buah lada dipengaruhi oleh kandungan dan kadar senyawa kimia di dalamnya. Proses ekstraksi buah lada hitam dalam skala industri digunakan pelarut etanol 60\% (Agoes, 2009). Senyawa piperin merupakan senyawa identitas yang paling banyak terkandung dalam buah lada serta memiliki beragam khasiat pengobatan, maka perlu dipisahkan secara selektif melalui penyarian atau ekstraksi.

Berdasarkan penelitian yang telah dilakukan sebelumnya, metode ekstraksi yang paling baik digunakan untuk mengisolasi piperin dari buah cabe jawa adalah ekstraksi dengan alat sokhlet jika dibandingkan dengan metode maserasi yang dianalisis menggunakan metode KLT-densitometri. Hasil yang diperoleh menunjukkan bahwa kadar piperin pada ekstrak cabe jawa yang diekstraksi dengan alat sokhlet dengan pelarut etanol 95\% lebih tinggi yaitu 15,75\% dibandingkan dengan kadar piperin pada ekstrak cabe jawa menggunakan metode maserasi yaitu sebesar 8,83\% (Istiqomah, 2013).

Penelitian ini didesain untuk mengetahui kadar piperin dalam ekstrak buah lada hitam dan lada putih yang diekstraksi dengan alat sokhlet menggunakan variasi konsentrasi etanol sehingga diharapkan dapat diperoleh informasi mengenai konsentrasi etanol yang dapat menghasilkan kadar piperin tertinggi pada ekstrak buah lada dan bermanfaat untuk pengembangan obat tradisional.

\section{METODE PENELITIAN}

Peralatan yang digunakan dalam penelitian ini antara lain adalah ayakan mesh 40, timbangan analitik (PIONEER), perangkat alat soxhlet, rotary evaporator (EYELA), water bath, indikator $\mathrm{pH}$ universal (NESCO), kertas saring, mikropipet, plat KLT silika gel $60 \mathrm{~F}_{254}$ (MERCK), chamber, UV-Box (CAMAG), 
perangkat alat Kromatografi Lapis Tipis (KLT)-Densitometri (CAMAG) dan alatalat gelas lain.

Bahan-bahan yang digunakan dalam penelitian ini yaitu simplisia buah lada putih (Piper nigrum L.) diperoleh dari Balai Penelitian Tanaman Rempah dan Obat (BALITTRO), Bogor, Jawa Barat pada bulan Maret 2016 dan diidentifikasi di Lembaga Ilmu Pengetahuan Indonesia (LIPI) Pusat Konservasi Tumbuhan Kebun Raya, Bogor, Indonesia. Standar piperin diperoleh dari UPT Sumber Daya Hayati, Padang pada bulan Juni 2016. Pelarut etanol (teknis), akuades, $\mathrm{H}_{2} \mathrm{SO}_{4}$ (Merck), eter (Merck), $\mathrm{NH}_{4} \mathrm{OH}$ (Merck), kloroform (Merck), etanol pro analisis (Merck), $n$-heksana (Merck) dan etil asetat (Merck).

JalannyaPenelitian

\section{A. Pembuatan Serbuk Simplisia}

Serbuk simplisia buah lada dibuat dari simplisia utuh yang diperoleh dari BALITTRO dengan cara diblender dan kemudian diayak dengan menggunakan ayakan mesh no.40.

\section{B. Pembuatan Ekstrak Etanol}

Serbuk simplisia sebanyak kurang lebih 50,0 g ditimbang seksama, kemudian diekstraksi dengan alat sokhlet menggunakan pelarut etanol dengan berbagai variasi konsentrasi 60\%, 70\%, dan 96\%. Ekstraksi dilakukan sampai tetesan siklus tidak berwarna lagi. Ekstrak cair yang diperoleh kemudian dipekatkan menggunakan rotary evaporator pada suhu $50^{\circ} \mathrm{C}$.

C. Pembuatan Fraksi Alkaloid

Ekstrak etanol yang diperoleh dilarutkan kembali dengan $\mathrm{H}_{2} \mathrm{SO}_{4} 2 \%$ hingga $\mathrm{pH}$ 3-4, kemudian ditambahkan eter hingga lemak menghilang. Selanjutnya fraksi eter dipisahkan dan fraksi asam dibasakan dengan $\mathrm{NH}_{4} \mathrm{OH} 25 \%$ sampai pH 9-10 dan diekstraksi kembali dengan kloroform sampai tidak berwarna (Abraham dkk., 2014). Fraksi kloroform selanjutnya disebut sebagai fraksi alkaloid.

D. Uji Kualitatif Keberadaan Senyawa Alkaloid dengan Metode KLT

Diambil cuplikan standar piperin, fraksi alkaloid buah lada, fraksi eter dan fraksi asam lalu dilarutkan dengan etanol. Ditotolkan masing-masing cuplikan 
pada plat KLT silika gel $60 \mathrm{~F}_{254}$ menggunakan pipa kapiler, kemudian dielusi menggunakan fase gerak campuran $n$-heksana : etil asetat (1:1). Noda diamati di bawah sinar UV pada panjang gelombang $254 \mathrm{~nm}$. Keberadaan alkaloid dideteksi dengan cara menyemprot plat menggunakan pereaksi Dragendorff dan dihitung masing-masing nilai $\mathrm{R}_{\mathrm{f}}$-nya.

E. Pembuatan Larutan Baku Standar Piperin

Larutan induk $(2000 \mu \mathrm{g} / \mathrm{mL})$ dibuat dengan menimbang seksama 50,0 mg standar piperin, kemudian dilarutkan dalam etanol p.a sampai tanda batas $25 \mathrm{~mL}$. Dibuat larutan deret standar piperin dengan 5 tingkat konsentrasi berbeda yaitu 200, 400, 600, 800 dan $1000 \mu \mathrm{g} / \mathrm{mL}$ dengan cara memipet sejumlah larutan dari larutan induk standar piperin dan dicukupkan dengan etanol p.a dalam labu ukur (Istiqomah, 2013).

F. Pembuatan Kurva Kalibrasi Standar Piperin

Larutan deret standar piperin kemudian ditotolkan masing-masing $5 \mu \mathrm{l}$ pada plat KLT silika gel $60 \mathrm{~F}_{254}$. Plat KLT selanjutnya dielusi dengan fase gerak campuran $n$-heksana : etil asetat (1:1) dan di-scanning sehingga dihasilkan data area standar piperin. Berdasarkan area terukur (y) pada berbagai baku kerja piperin (x), maka dapat dihitung harga koefisien korelasi (r). Bila ada hubungan linear antara $\mathrm{y}$ dengan $\mathrm{x}$ maka dihitung persamaan garis regresi $\mathrm{y}=\mathrm{bx}+\mathrm{a}$ (Harmita, 2004).

\section{G. Pembuatan Larutan Uji}

Ditimbang seksama kurang lebih 50 mg ekstrak buah lada hitam, dilarutkan dengan etanol dalam labu ukur $50 \mathrm{~mL}$ sehingga diperoleh konsentrasi $1000 \mu \mathrm{g} / \mathrm{mL}$. Dibuat larutan uji konsentrasi $800 \mu \mathrm{g} / \mathrm{mL}$, dengan memipet $20 \mathrm{~mL}$ dalam labu terukur $25 \mathrm{~mL}$ lalu ditambahkan etanol p.a hingga tanda batas.

H. Pengukuran Kadar Piperin

Ditotolkan masing-masing $5 \mu \mathrm{L}$ larutan standar yang telah diencerkan dan larutan uji pada plat KLT silika gel $60 \mathrm{~F}_{254}$. Plat selanjutnya dielusi dengan fase gerak $n$-heksana : etil asetat (1:1), dan diukur dengan densitometer pada panjang gelombang $254 \mathrm{~nm}$. Data luas area yang didapatkan dari baku standar piperin kemudian dibuat persamaan kurva baku dengan bantuan Microsoft Excel 2007. Persamaan kurva baku yaitu $\mathrm{y}=\mathrm{bx}+\mathrm{a}$ dengan $\mathrm{y}=$ luas area, $\mathrm{x}=$ kadar piperin 
$(\mu \mathrm{g} / \mathrm{mL})$. Luas area sampel yang didapatkan dari hasil scan pada alat densitometer kemudian dimasukkan ke dalam persamaan garis kurva baku, maka didapatkan masing-masing persentase kadar piperin pada ekstrak buah lada hitam (Murrukmihadi dkk., 2013).

\section{HASIL DAN PEMBAHASAN}

\section{A. Ekstraksi}

Metode ekstraksi yang dipilih untuk mengekstraksi adalah metode yang cocok dengan sifat bahan yang digunakan. Metode ekstraksi dengan alat sokhlet merupakan salah satu metode yang cocok untuk mengekstraksi alkaloid (Harbone, 1996). Penggunaan pelarut yang ideal untuk mengekstraksi adalah pelarut yang menunjukkan selektivitas maksimal, mempunyai kapasitas terbaik, dan kompatibel dengan sifat bahan yang diekstraksi (Agoes, 2007). Penggunaan cairan pelarut pengekstraksi berupa campuran etanol-air mengandung air yang cukup untuk membantu proses difusi pelarut ke dalam sel. Proses difusi biasanya akan ditingkatkan apabila sel tanaman mengalami perlakuan dengan air, atau pelarut yang mengandung air, yang akan menyebabkan terjadinya pengembangan (swelling) sel sehingga terjadi peningkatan permeabilitas atau pecahnya dinding sel (Agoes, 2009).

Tabel I. Hasil rendemen ekstrak etanol buah lada terhadap simplisia kering*

\begin{tabular}{ccc}
\hline \multirow{2}{*}{ Pelarut pengekstraksi } & \multicolumn{2}{c}{ Rerata rendemen ekstrak etanol (\%) \pm SD } \\
\cline { 2 - 3 } & Buah lada hitam & Buah lada putih \\
\hline Etanol 60\% & $40,82 \pm 1,07$ & $20,10 \pm 0,44$ \\
Etanol 70\% & $14,85 \pm 0,91$ & $22,46 \pm 1,64$ \\
Etanol 96\% & $11,98 \pm 1,29$ & $36,10 \pm 1,29$ \\
\hline
\end{tabular}

*pengujian dilakukan dengan 3 kali pengulangan

Berdasarkan hasil ekstraksi dengan pelarut etanol pada Tabel I, perbedaan rendemen yang diperoleh menunjukkan bahwa dengan adanya perbedaan konsentrasi etanol yang digunakan untuk ekstraksi dapat mempengaruhi rendemen yang dihasilkan. Besar kecilnya persentase rendemen ekstrak menunjukkan keefektifan proses ekstraksi, artinya banyaknya zat aktif yang ikut terekstraksi juga dapat dilihat dari besarnya nilai rendemen ini. Pada ekstraksi buah lada 
hitam, pelarut etanol $60 \%$ merupakan pelarut yang paling banyak menghasilkan rendemen ekstrak, sedangkan pada ekstraksi buah lada putih, pelarut etanol 96\% merupakan pelarut yang paling banyak menghasilkan rendemen ekstrak.

Selanjutnya, pembuatan fraksi alkaloid dilakukan untuk menghindari gangguan selama penetapan kadar piperin dari metabolit sekunder selain alkaloid yang terdapat pada bahan. Fraksi alkaloid diperoleh melalui proses ekstraksi dengan teknik ekstraksi asam-basa. Alkaloid mudah larut dalam air jika berupa garam, dengan penambahan asam. Alkaloid dalam bentuk bebas atau bentuk basanya mudah larut dalam pelarut organik namun sukar larut dalam air (Sirait 2007). Berdasarkan hasil pada Tabel II, baik pada buah lada hitam maupun buah lada putih yang diekstraksi dengan pelarut pengesktraksi etanol 96\% menghasilkan rendemen fraksi alkaloid paling besar.

Tabel II. Hasil rendemen fraksi alkaloid dari ekstrak etanol buah lada*

\begin{tabular}{ccc}
\hline \multirow{2}{*}{ Pelarut pengekstraksi } & $\begin{array}{c}\text { Rerata rendemen fraksi alkaloid terhadap } \\
\text { ekstrak etanol (\%) } \pm \text { SD }\end{array}$ \\
\cline { 2 - 3 } & Buah lada hitam & Buah lada putih \\
\hline $60 \%$ & $18,25 \pm 0,78$ & $17,01 \pm 0,49$ \\
$70 \%$ & $20,46 \pm 1,69$ & $18,46 \pm 0,48$ \\
$96 \%$ & $28,22 \pm 1,16$ & $20,31 \pm 0,58$ \\
\hline
\end{tabular}

*pengujian dilakukan dengan 3 replikasi

\section{B. Uji Kualitatif Keberadaan Senyawa Alkaloid dengan Metode KLT}

Proses identifikasi keberadaan senyawa alkaloid yang terkandung dalam ekstrak dilakukan dengan uji kualitatif menggunakan metode KLT. Pada pengujian ini, keberadaan senyawa alkaloid tidak hanya diujikan untuk sampel fraksi alkaloid dari ekstrak etanolnya saja, tetapi juga fraksi eter dan fraksi asam. Pada Gambar 1, dapat dilihat bahwa sampel ekstrak menunjukkan keberadaan piperin karena sampel memberikan noda pada nilai $R_{\mathrm{f}}$ yang mirip dengan standar piperin, yaitu sekitar 0,6 dengan deteksi menggunakan sinar UV $254 \mathrm{~nm}$, sedangkan pada fraksi eter dan fraksi asam tidak tampak noda. Hal ini berarti bahwa proses ekstraksi asam-basa yang dilakukan untuk menarik alkaloid, termasuk piperin, dalam ekstrak etanol sudah maksimal. 


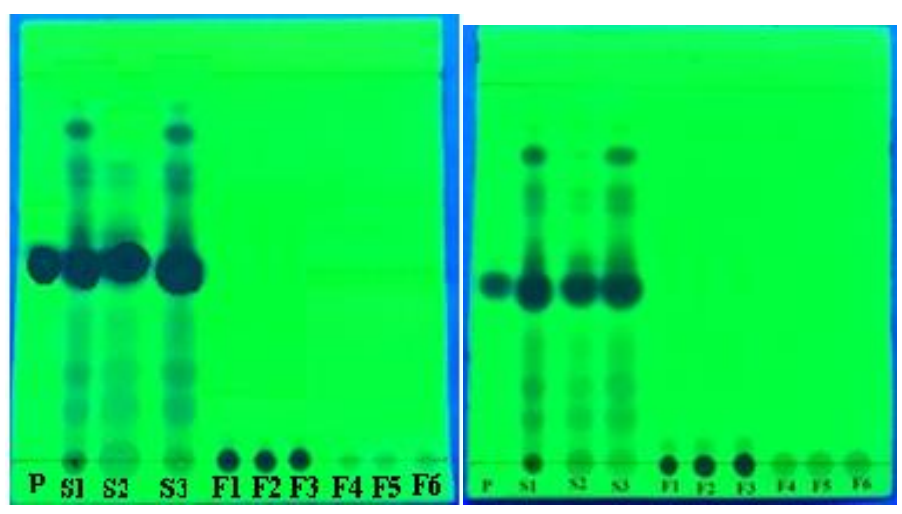

(a)

(b)

Gambar 1. Hasil identifikasi keberadaan senyawa alkaloid pada fraksi alkaloid dari ekstrak etanol lada hitam (a) dan lada putih (b) pada plat KLT dengan pengamatan di bawah sinar UV $254 \mathrm{~nm}$

\section{Keterangan:}

$\mathrm{P}=$ Standar piperin

$\mathrm{S} 1=$ Fraksi alkaloid dari ekstrak etanol $60 \%$

S2 $=$ Fraksi alkaloid dari ekstrak etanol 70\%

S3 $=$ Fraksi alkaloid dari ekstrak etanol $96 \%$

$\mathrm{F} 1=$ Fraksi eter dari ekstrak etanol $60 \%$

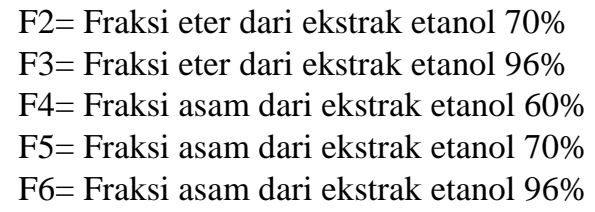

Pada Gambar 2, deteksi dilanjutkan dengan menggunakan pereaksi Dragendorff untuk memastikan bahwa bercak tersebut adalah senyawa alkaloid. Keberadaan senyawa alkaloid ditegaskan jika hasil penyemprotan terbentuk noda berwarna jingga pada plat. Hasil menunjukkan, standar piperin dan sampel ekstrak alkaloid dari ekstrak etanol memberikan bercak berwarna jingga setelah penotolan, sedangkan pada fraksi eter dan fraksi asam sudah tidak menimbulkan bercak, yang menandakan proses ekstraksi alkaloid telah dilakukan dengan maksimal.

Berdasarkan Gambar 1 dan 2, jarak noda yang diperoleh antara standar piperin dengan sampel tidak jauh berbeda, hal ini menunjukkan bahwa ekstrak buah lada putih positif mengandung senyawa aktif piperin. Penegasan adanya senyawa alkaloid dilakukan menggunakan pereaksi semprot Dragendorff, dimana terdapat bercak jingga di plat pada penotolan standar piperin dan sampel fraksi alkaloid dari ekstrak etanol sedangkan pada fraksi eter dan fraksi air sudah tidak menimbulkan bercak, yang menandakan proses ekstraksi alkaloid dengan teknik ekstraksi asam basa telah dilakukan dengan maksimal. 


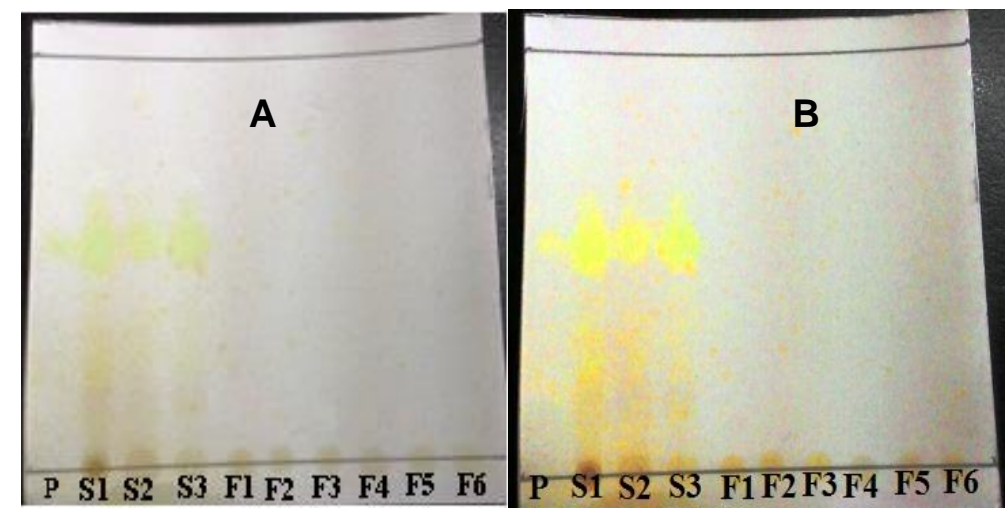

(a)

(b)
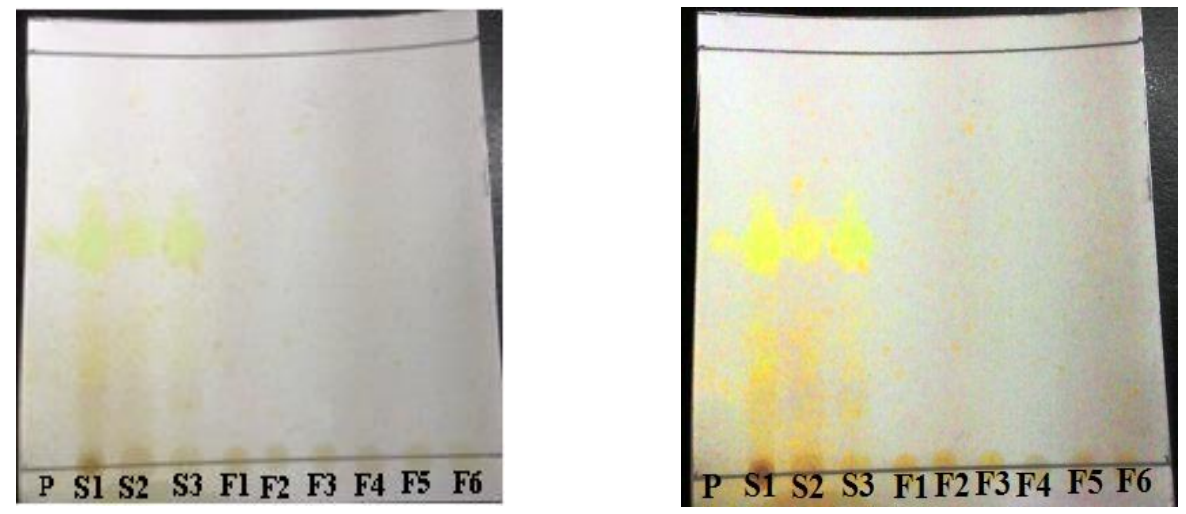

Gambar 2. Hasil identifikasi keberadaan senyawa alkaloid pada fraksi alkaloid dari ekstrak etanol lada hitam (a) dan lada putih (b) pada plat KLT setelah disemprot dengan pereaksi Dragendorff

\section{Keterangan:}

$\mathrm{P}=$ Standar Piperin

S1= Fraksi alkaloid dari ekstrak etanol $60 \%$

S2 $=$ Fraksi alkaloid dari ekstrak etanol 70\%

F2 $=$ Fraksi eter dari ekstrak etanol 70\%

F3= Fraksi eter dari ekstrak etanol $96 \%$

S3= Fraksi alkaloid dari ekstrak etanol 96\%

$\mathrm{F} 1=$ Fraksi eter dari ekstrak etanol $60 \%$

F4= Fraksi asam dari ekstrak etanol $60 \%$

F5= Fraksi asam dari ekstrak etanol 70\%

F6= Fraksi asam dari ekstrak etanol 96\%

\section{Penetapan Kadar Piperin}

Penetapan kadar piperin dapat dilakukan menggunakan metode KLTdensitometri. Metode tersebut banyak digunakan dalam analisis kualitatif ataupun kuantitatif di bidang farmasi terutama di bidang analisis obat bahan alam. Analisis kuantitatif yaitu dengan cara penentuan luas area atau luas bercak kromatogram yang dapat dilakukan dengan menggunakan baku pembanding dan menggunakan kurva kalibrasi baku pembanding (Redja dkk., 2009). 
Pada penelitian ini, digunakan plat KLT silika gel $60 \mathrm{~F}_{254}$ sebagai fase diam dan fase geraknya menggunakan $n$-heksana : etil asetat (1:1). Menurut Rohman (2009) fase gerak harus diatur sedemikian rupa sehingga harga $R_{f}$ solut terletak antara 0,2-0,8 untuk memaksimalkan pemisahan. Fase gerak $n$-heksana : etil asetat digunakan karena bersifat semi polar sehingga dapat memisahkan piperin yang juga bersifat semipolar dari kandungan ekstrak lainnya. Selain itu, $n$ heksana:etil asetat (1:1) memiliki nilai $R_{f}$ yang memenuhi syarat sebagai fase gerak yang optimal.

Tabel III. Luas area standar piperin

\begin{tabular}{cc}
\hline $\begin{array}{c}\text { Konsentrasi piperin } \\
(\boldsymbol{\mu} \mathbf{g} / \mathbf{m L})\end{array}$ & Luas Area \\
\hline 200 & 6691,9 \\
400 & 12448,0 \\
600 & 17138,8 \\
800 & 19082,6 \\
1000 & 22384,7 \\
\hline
\end{tabular}

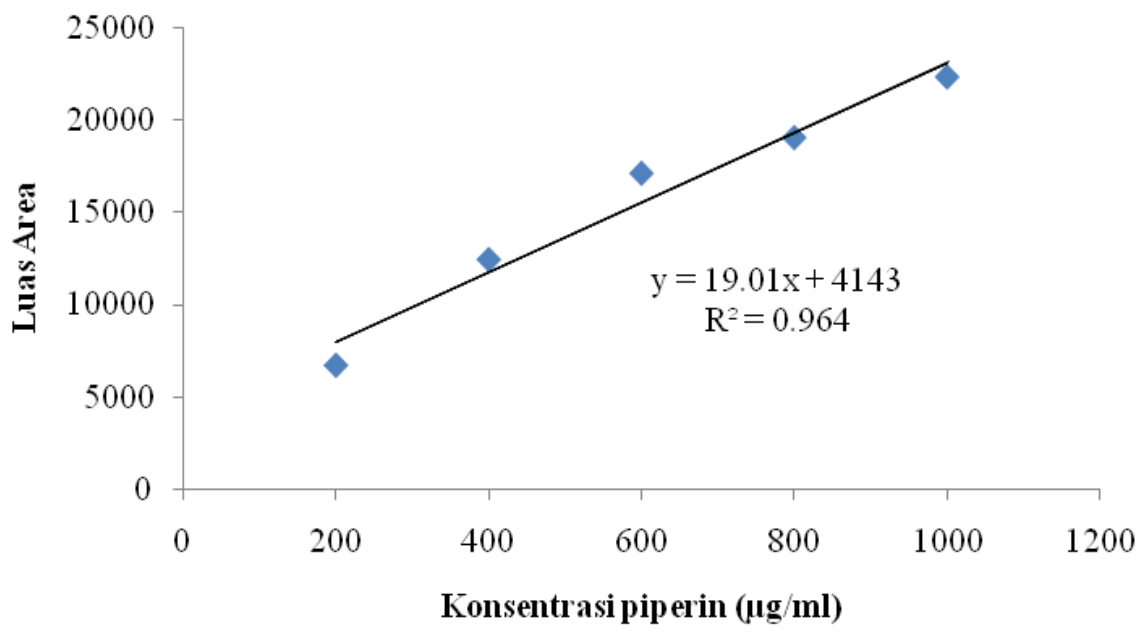

Gambar 3. Hubungan konsentrasi piperin dengan luas area yang diukur dengan KLT-densitometri

Hasil pembuatan kurva kalibrasi piperin menunjukkan adanya hubungan linear antara kadar piperin dengan luas area yaitu semakin tinggi konsentrasi 
piperin maka semakin besar luas area yang terbaca pada alat densitometer. Persamaan garis linear yang diperoleh adalah $y=19,0101 x+4143,14$ dengan nilai koefisien korelasi sebesar 0,9823, seperti yang terlihat pada Tabel III dan Gambar 3.

Menggunakan persamaan tersebut, luas area sampel dari hasil pengukuran masing-masing sampel dimasukkan ke dalam persamaan garis linear sehingga diperoleh kadar piperin dalam fraksi alkaloid dari ekstrak etanol buah lada. Hasil penetapan kadar piperin pada sampel ekstrak buah lada ditunjukkan pada Tabel IV.

Tabel IV. Hasil kadar piperin dalam fraksialkaloid dari ekstrak etanol buah lada

\begin{tabular}{cccc}
\hline $\begin{array}{c}\text { Ekstrak etanol } \\
\text { Buah lada hitam }\end{array}$ & $\begin{array}{c}\text { Rata-rata kadar } \\
\text { piperin (\%) } \mathbf{\text { SD }}\end{array}$ & $\begin{array}{c}\text { Ekstrak etanol } \\
\text { Buah lada putih }\end{array}$ & $\begin{array}{c}\text { Rata-rata kadar } \\
\text { piperin (\%) } \pm \text { SD }\end{array}$ \\
\hline $60 \%$ & $52,81 \pm 4,66$ & $60 \%$ & $27,12 \pm 4,59$ \\
$70 \%$ & $47,06 \pm 2,46$ & $70 \%$ & $30,57 \pm 12,81$ \\
$96 \%$ & $36,97 \pm 11,95$ & $96 \%$ & $38,72 \pm 8,28$ \\
\hline
\end{tabular}

Berdasarkan hasil yang diperoleh, pada penentuan kadar piperin dalam fraksi alkaloid buah lada hitam menggunakan metode KLT-densitometri terlihat bahwa kadar piperin tertinggi pada fraksi alkaloid dari ekstrak etanol buah lada hitam yang diekstraksi menggunakan pelarut etanol $60 \%$ yaitu sebesar 52,81\%. Semakin besar konsentrasi etanol maka semakin kecil kadar piperin dalam ekstrak buah lada hitam. Kadar piperin tertinggi diperoleh dari fraksi alkaloid dari ekstrak etanol buah lada putih yang diekstraksi menggunakan pelarut etanol 96\% yaitu sebesar 38,72\%. Semakin besar konsentrasi etanol maka semakin besar kadar piperin dalam ekstrak buah lada putih. Hal ini membuktikan bahwa perbedaan konsentrasi pelarut pengekstraksi berpengaruh pada kadar piperin yang ikut tersari selama proses ekstraksi.

Angka persentase kadar piperin dalam sampel cukup besar karena penentuan kadar piperin dilakukan pada fraksi alkaloid dari ekstrak etanolnya, dengan kata lain kadar piperin tersebut menunjukkan jumlah kandungan piperin dari jumlah alkaloid keseluruhan dalam ekstrak buah lada. Buah lada hitam mengandung piperin yang lebih banyak dibanding dengan buah lada putih. Hal ini diduga karena asal simplisia keduanya sehingga mempengaruhi kadar piperin di 
dalamnya, dimana lada putih diperoleh dari buah lada hitam yang buah-buahnya dipetik selagi masih hijau atau hampir masak, direndam untuk memudahkan pengupasan lapisan luar perikarp, lalu dijemur sampai kering (Kartasapoetra, 2004).

\section{KESIMPULAN}

Kadar piperin tertinggi diperoleh dari ekstrak buah lada hitam menggunakan

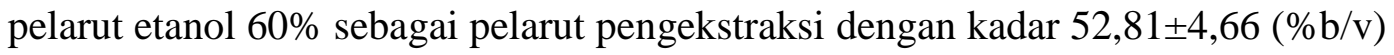
terhadap fraksi alkaloidnya. Kadar piperin tertinggi diperoleh dari ekstrak buah lada putih menggunakan pelarut etanol dengan konsentrasi $96 \%$ sebagai pelarut pengekstraksi dengan kadar 38,72 $\pm 8,28(\% \mathrm{~b} / \mathrm{v})$ terhadap fraksi alkaloidnya.

\section{DAFTAR PUSTAKA}

Abraham, A., Fauziyah, B., Fasya, A.G., dan Adi, T.K., 2014, Uji Antitoksoplasma Ekstrak Kasar Alkaloid Daun Pulai (Alstonia scholaris, (L.) R. BR) terhadap Mencit (Mus musculus) BALB/C yang Terinfeksi Toxoplasma Gondii Strain Rh. Alchemy. 3 (1): 67-75.

Agoes, G., 2007, Teknologi Bahan Alam, Penerbit ITB, Bandung, 32-35.

Agoes, G., 2009, Teknologi Bahan Alam, Edisi revisi, Penerbit ITB, Bandung, 37 dan 85 .

Depkes RI., 1980, Materia Medika Indonesia. Jilid IV, Jakarta: Badan Pengawas Obat dan Makanan, 99-108.

Harborne, J.B., 1996, Metode Fitokimia: Penuntun Cara Modern Menganalisa Tumbuhan, Terjemahan: Kosasih Padmawinata dan Iwang Soediro. Penerbit ITB, Bandung.

Harmita, 2004, Petunjuk Pelaksanaan Validasi Metode dan Cara Perhitungannya, Majalah Ilmu Kefarmasian,1 (3): 117-135.

Istiqomah, 2013, Perbandingan Metode Ekstraksi Maserasi dan Sokletasi terhadap Kadar Piperin Buah Cabe Jawa (Piperis retfofracti fructus), Skripsi, Fakultas Kedokteran dan Ilmu Kesehatan, UIN Syarif Hidayatullah, Jakarta.

Kar, A., 2014, Farmakognosi dan Farmakobioteknologi, Terjemahan: July Manurung dkk., Penerbit Buku Kedokteran EGC, Jakarta. 2 (2): 503-504. 
Kartasapoetra, G., 2004, Budidaya Tanaman Berkhasiat Obat, Jakarta: PT Rineka Cipta, 50-51.

Kolhe, S.R., Borole, P., and Patel, U., 2011, Extraction and Evaluation of Piperine from Piper nigrum, Internasional Journal of Applied Biology and Pharmaceutical Technology, 144-149.

Loo, T., 1987, Ikhtisar Ringkas dari Dasar-Dasar Farmakognosi, Bunda Karya, Jakarta, 181.

Murrukmihadi, M., Wahyuono, S., Marchaban, dan Martono, S., 2013, Penetapan Kadar Alkaloid dari Ekstrak Etanolik Bunga Kembang Sepatu (Hibiscus rosa-sinensis L.), Traditional Medicine Journal, 18 (2): 118-120.

Redja, I.W., Aziz, Z., Yantih, N., 2009, Analisis Instrumental, Jakarta: Fakultas Farmasi Universitas Pancasila, 133-140.

Rohman, A., 2009, Kromatografi Untuk Analisis Obat, Edisi Ke-1, Graha Ilmu, Yogyakarta. 47, 49, 56.

Sabina, E.P., Nasreen, A., Vedi, M., and Rasool, M., 2013, Analgesic, Antipyretic and Ulcerogenic Effects of Piperine: An Active Ingredient of Pepper, Journal of Pharmaceutical Sciences and Research, 5 (10): 203-206.

Sirait, M., 2007, Penuntunan Fitokimia dalam Farmasi, Bandung: ITB, 60-61.

Vasavirama, K.and Upender, M., 2014, Piperine: A Valuable Alkaloid from Piper Species, International Journal of Pharmacy and Pharmaceutical Sciences, 6 (4): 34-38. 